\title{
PENGEMBANGAN TERNAK AYAM KAMPUNG MELALUI PENERAPAN TEKNOLOGI INSEMINASI BUATAN DAN PEMANFAATAN PAKAN LOKAL DI KOTA KENDARI
}

\section{Development of Ayam Kampung Through Application of Artificial Insemination Technology and Utilization of Local Feed in Kendari City}

\author{
Nur Santy Asminaya*, Andi Murlina Tasse, Natsir Sandiah, Nuraini, Rusli Badaruddin, \\ Amiludin Indi, Astriana Napirah, Hairil Azulyatno Hadini, Wa Laili Salido \\ Jurusan Peternakan, Fakultas Peternakan, Universitas Halu Oleo
}

\section{Article history \\ Received: Jul 02, 2021; \\ Accepted: Nov 04, 2021 \\ * Corresponding author: \\ E-mail: \\ nur.asminaya@uho.ac.id \\ DOI: https://doi.org/10.465 49/igkojei.v2i3.238}

\section{(c) (i)(2) (A) ${ }_{\text {OPEN }}$ access}

\begin{abstract}
The supply DOC of super-free-range chicken in Southeast Sulawesi until now still comes from outside. This causes the DOC price to be quite expensive due to the high cost of transportation in the distribution process. The current pandemic also made it more difficult to obtain DOC from outside which caused the lack of supply of super-free-range chicken. Therefore, it is necessary to independently procure a source of DOC said chicken. This community service aims to provide a source of information and training in the use of AI technology and the use of feed based on local feed ingredients to the community through the FPT-UHO Village Development Program. This service is carried out in a group of native chicken farmers in Mokoau Village, Kambu sub-district, Kendari City by involving various components such as community leaders, youth, and government officials. This activity is carried out through online and offline presentations and training. The results obtained in this service are in the form of DOC (according to standards), free-range chickens that have high body weight, free-range chicken feed based on local feed resources, scientific articles, and theses. Conclusion:the FPT-UHO village development program can improve the ability of farmers to utilize AI technology and feed processing technology based on local feed ingredients.
\end{abstract}

Keywords: DOC; feed; Livestock; Super free-range chicken; Technology

\section{ABSTRAK}

Pasokan DOC ayam kampung super di Sulawesi Tenggara hingga saat ini masih berasal dari luar yang mengakibatkan harga DOC tinggi karena mahalnya biaya transportasi. Masa pandemi juga menjadikan situasi lebih sulit untuk memperoleh DOC dari luar yang berdampak pada kurangnya pasokan daging ayam kampung super. Oleh karena itu, perlu adanya pengadaan sumber DOC ayam kampung secara mandiri. Tujuan kegiatan ini memberikan sumber informasi dan pelatihan dalam pemanfaatan teknologi IB dan pemanfaatan pakan berbasis bahan pakan lokal kepada masyarakat melalui Program Bina Desa FPT-UHO. Pengabdian ini dilakukan di kelompok peternak ayam kampung di Kelurahan Mokoau, kecamatan Kambu, Kota Kendari dengan melibatkan berbagai komponen seperti tokoh masyarakat, pemuda dan aparat pemerintah. Kegiatan ini dilakukan dengan cara persentasi dan pelatihan secara daring dan luring. Hasil yang diperoleh dalam pengabdian ini berupa DOC (sesuai dengan standar), ayam kampung yang memiliki bobot badan yang tinggi, pakan ayam kampung berbasis sumber daya pakan lokal, artikel ilmiah dan skripsi. Kesimpulan: program bina desa FPT-UHO mampu meningkatkan kemampuan peternak untuk memanfaatkan teknologi IB dan teknologi pengolahan pakan berbasis bahan pakan lokal.

Kata kunci: Ayam kampung super; DOC; Pakan; Teknologi; Ternak. 


\section{PENDAHULUAN}

Dampak ekonomi dari pandemi covid 19 memiliki efek dramatis pada kesejahteraan banyak keluarga dan masyarakat. Kota Kendari kini telah memasuki status new normal dimana masyarakat sudah dapat beraktivitas dan melakukan pekerjaan seperti biasa. Pemerintah kota tetap menekankan penerapan prokes covid 19 dengan membuat surat edaran untuk tetap mematuhi protokol covid-19 seperti menggunakan masker, tetap menjaga jarak dan selalu membawa heand sanitaizer serta selalu mencuci tangan sebelum dan sesudah beraktivitas. Seiring dengan berjalannya waktu, banyak hal yang ditimbulkan dari penyebaran covid-19. Peternak ayam kampung super dimasa pandemi mengalami penurunan penghasilan yang disebabkan oleh sulitnya peternak mendapatkan bibit ayam kampung super yang selama ini selalu didatangkan dari pulau Jawa.

Salah satu kendala dalam penyediaan bibit ayam kampung super adalah minimnya pengetahuan peternak tentang teknologi reproduksi pada ayam. Teknologi Inseminasi Buatan (IB) merupakan solusi yang dapat ditawarkan kepada peternak di Kota Kendari untuk dapat memenuhi ketersediaan bibit ayam kampung super. Kegiatan Program Bina Desa Fakultas Peternakan Universitas Halu Oleo (FPT UHO) berupaya memberikan kontribusi dan partisipasi aktif secara penuh terhadap penyelesaian masalah-masalah yang dihadapi kelompok pembudidaya ayam kampung yang ada di Kota Kendari. Kegiatan ini bertujuan untuk meningkatkan kemampuan peternak dalam penerapan teknologi IB dan teknologi pengolahan pakan berbasis bahan pakan lokal sehingga usaha ternak budidaya ayam kampung dapat berkembang dan dapat bersaing dengan jenis ternak unggas lain, baikdi pasar-pasar tradisional dan rumah makan maupun dijual ke pasar modern (swalayan) serta dipasarkan secara online dimedia social, yang pada akhirnya mampu meningkatkan pendapatan peternak terutama dimasa pandemi covid-19.

\section{METODE}

Kegiatan pengabdian kepada masyarakat (PKM) ini dilaksanakan pada awal sampai akhir Desember 2020 di kelompok tani ternak Kelurahan Mokoau, Kecamatan Kambu, Kota Kendari. Peserta pengabdian ini adalah petani ternak ayam kampung di Kelurahan Mokoau Kota Kendari. Bahan yang digunakan adalah ayam kampung unggul, semen ayam kampung unggul, pakan berbasis sumber bahan pakan lokal, $\mathrm{Em} 4$, gula dan $\mathrm{NaCl}$ fisiologis $19 \%$. Alat yang digunakan terdiri atas seperangkat alat IB, mesin tetas, ember, terpal dan silo.

Kegiatan pengabdian di awali dengan survei lokasi secara langsung kemudian dilakukan sosialisasi secara daring dan bimbingan secara luring di lokasi kandang petani ternak Kelurahan Mokoau. Kegiatan pengabdian selain diikuti oleh petani ternak, juga melibatkan berbagai komponen seperti tokoh masyarakat, pemuda dan aparat pemerintah. Keberhasilan dan peningkatan kemampuan 
peserta diukur dengan pengamatan secara langsung selama pelaksanaan kegiatan berlangsung. Data yang diperoleh selanjutkan dianalisis dan disampaikan secara deskriptif.

\section{HASIL DAN PEMBAHASAN}

\section{PELAKSANAAN SURVEI}

Kegiatan PKM ini diawali dengan melakukan survei lapangan terhadap kondisi lokasi kegiatan secara langsung langsung (luring) (Gambar 1). Meskipun dilakukan secara luring, kegiatan dilaksananakan dengan tetap memperhatikan protokol pencegahan penularan Covid-19.
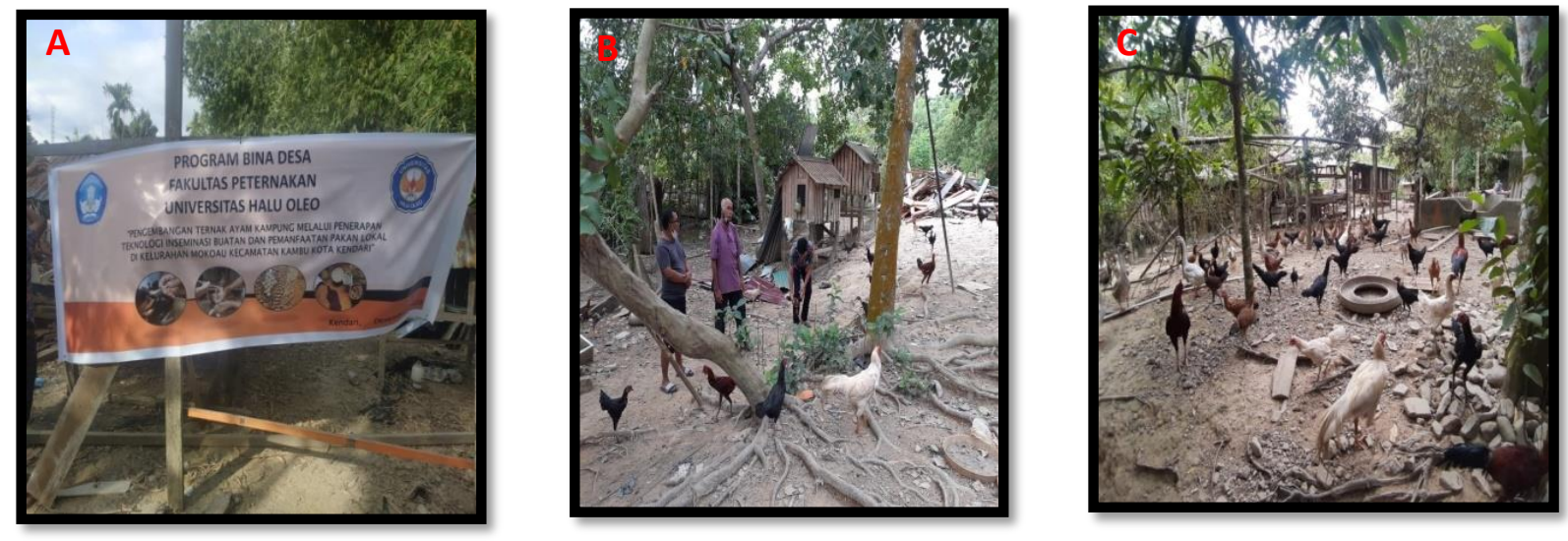

Gambar 1. Survei lokasi petani ternak secara luring, (A) Spanduk pelaksanaan program, (B) Pelaksanaan sosialisasi dan (C) Kondisi ternak peternak di lokasi survei

Pelaksanaan kegiatan secara luring dilakukan karena beberapa peternak belum mengetahui penggunaan aplikasi jika kegiatan dilakukan secara daring. Hal ini sesuai dengan pendapat Rigianti (2020) yang melaporkan bahwa kendala yang dialami selama proses pembelajaran secara during adalah aplikasi, jaringan internet dan gawai. Ditambahkan oleh Indarjulianto et al. (2021) bahwa kedepannya sangat perlu dilakukan sosialisasi sistem pembelajaran atau komunikasi kepada masyarakat termasuk petani peternak secara daring.

\section{PENERAPAN TEHNIK INSEMINASI BUATAN}

Inseminasi buatan atau kawin suntik adalah upaya memasukkan semen/mani ke dalam saluran reproduksi hewan betina yang sedang birahi dengan bantuan inseminator agar hewan bunting (Herawati et al., 2012). Semua petani ternak yang hadir dalam kegiatan ini sangat antusias dan sangat interaktif dalam mengikuti pemaparan materi dan praktek teknik IB yang diberikan. Penerapan teknik IB, bertujuan untuk meningkatkan kemampuan reproduksi ayam betina untuk menghasilkan telur tetas dan meningkatkan produksi DOC yang seragam dalam waktu relatif singkat serta efisiensi penggunaan pejantan.

Kegiatan pertama yang dilakukan dalam penerapan teknologi IB adalah pengambilan semen pada ternak jantan, (Gambar 2). Pengambilan semen dilakukan oleh 2 orang (satu orang melakukan 
handling dan mengurut ayam sementara yang lain menampung sperma dengan tabung penampung sperma). Pengambilan sperma dapat dilakukan 3-4 kali seminggu pada sore hari diatas pukul 15.00. Sperma yang sudah diperoleh diencerkan dengan menggunakan $\mathrm{NaCl}$ Fisiologis sehingga dapat membuahi banyak betina. Sperma yang sudah diencerkan tidak dapat disimpan terlalu lama dan harus dihindarkan dari sinar matahari secara langsung. Semen yang telah siap selanjutnya dimasukkan ke dalam saluran reproduksi betina
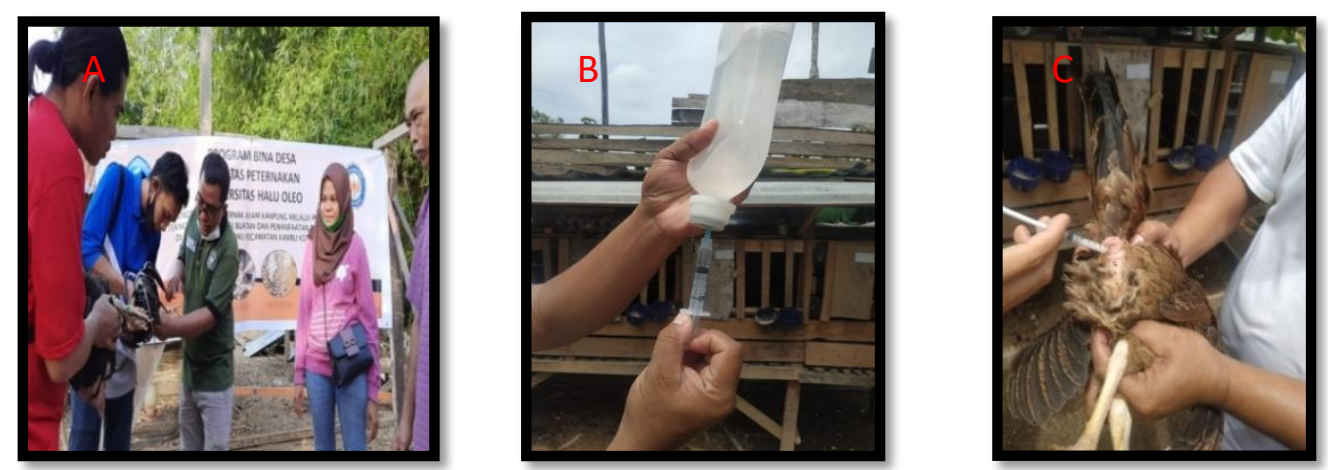

Gambar 2. Proses IB. (A). Pengambilan semen pada ayam jantan, (B) Pengambilan $\mathrm{NaCl}$ dan (C) Memasukkan semen ke dalam saluran reproduksi betina

Jumlah ayam jantan yang berhasil ditampung semennya sebanyak 3 ekor, dan volume semen yang dihasilkan per satu kali ejakulasi adalah sebesar $0,5 \mathrm{ml}$, dan setelah mengalami pengenceran dengan $\mathrm{NaCL}$ fisiologis maka volume semennya bertambah menjadi $1 \mathrm{ml}$, dan jumlah ayam betina yang bisa dikawini sebanyak 5-10 ekor. Kegiatan penyuluhan dan praktek PKM ini diikuti oleh 10 orang anggota kelompok mitra. Kegiatan pengabdian ini juga telah menghasilkan 6 orang peternak yang terampil dalam melakukan IB pada ternak ayam. Jumlah peternak yang terampil melakukan IB ini diyakini akan bertambah seiring berjalannya praktek langsung pada masyarakat. Hal ini sesuai dengan yang dikemukakan oleh Abadi et al. (2020) yang menyatakan bahwa kegiatan IB pada ayam dapat meningkatkan partisipasi dan keterampilan peternak ayam di Kelurahan Lalodati Kecamatan Puuwatu Kota Kendari.

\section{PENERAPAN PENGolahan PAKAN BERbasis BAHAN BAKU LOKAL}

Usaha peternakan yang dijalankan kelompok mitra belum optimal antara lain disebabkan proses manajemen usaha yang masih sederhana dan belum ada sentuhan teknologi yang dilakukan. Kegiatan sosialisasi dan penyuluhan mengenai perbaikan manajemen usaha, khususnya manajemen produksi dan pakan ternak, dilakukan agar peternak mendapat gambaran penerapan teknologi pada aspek tersebut (Gambar 3).

Penyuluhan dan praktek pembuatan pakan berbasis pakan lokal dalam kegiatan PKM ini diikuti oleh 8 orang anggota kelompok mitra. Pembuatan pakan ternak dengan bahan baku lokal dalam kegiatan ini menggunakan teknologi sederhana yaitu fermentasi menggunakan EM4 yang bisa 
diperoleh mitra ditoko ternak sekitar. Teknologi fermentasi adalah teknologi pemecahan senyawa organik menjadi senyawa yang lebih sederhana dengan melibatkan mikroorganisme dalam keadaan anaerob (Pamungkas, 2011). Dalam proses ini terjadi perubahan kimia seperti perubahan struktur kimia nutrisi dari protein menjadi asam amino dan fisik yakni aroma pakan yang lebih harum dan disukai ternak, sehingga meningkatkan kecernaan pakan dan palatabilitas ternak

Pakan memegang peranan 60-70\% dari biaya produksi usaha peternakan (Pagala et al., 2020). Umumnya kelompok peternak mitra menggunakan pakan konvensional yang diperoleh di toko-toko ternak sekitar kota Kendari. Namun seiring berjalannya waktu kelompok mitra mengalami masalah pada biaya produksi yang semakin tinggi karena harga pakan yang terus naik setiap tahun.
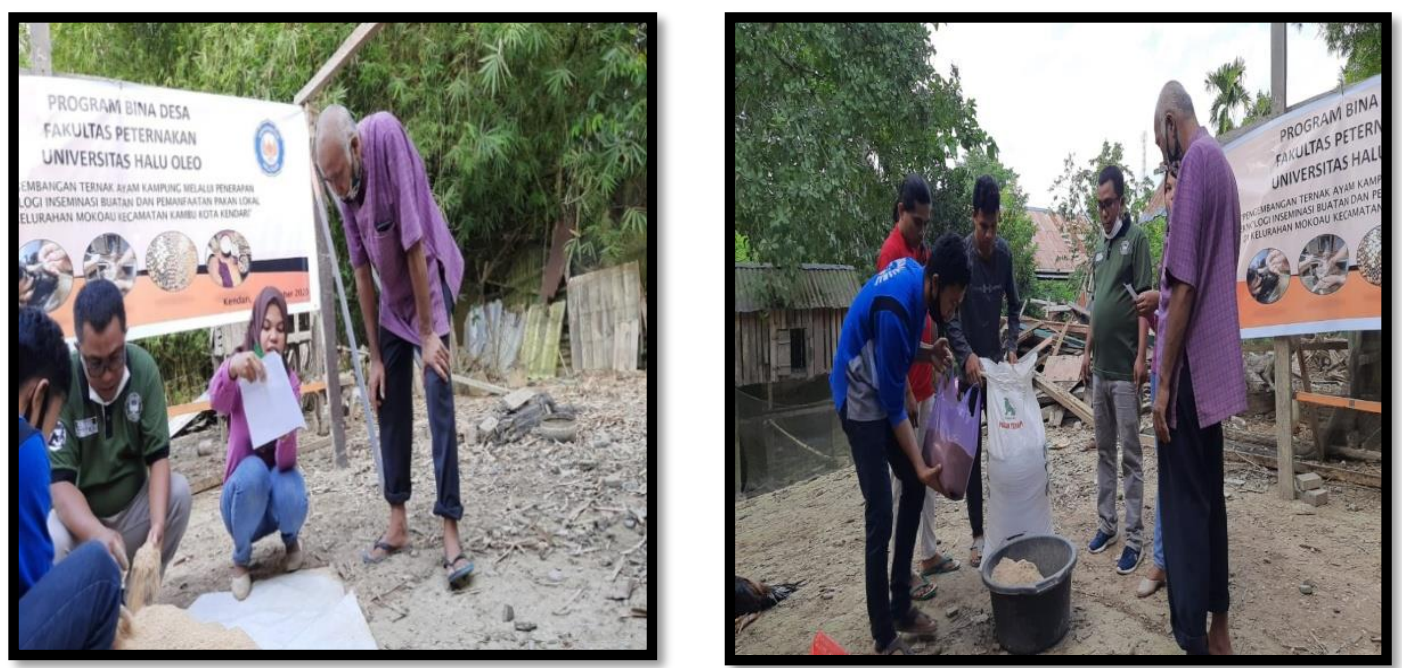

Gambar 3. Kegiatan penyuluhan produksi dan pakan ternak. (A) penyuluhan pakan ternak, (B) Kegiatan formulasi pakan ternak

Salah satu upaya yang dilakukan untuk mengatasi masalah tersebut melalui pemanfaatan bahan pakan lokal dengan harga yang lebih murah dan mudah diperoleh disekitar peternakan kelompok mitra. Bahan pakan lokal yang dimaksud adalah jagung, konsentrat, dedak, limbah pasar, dan limbah hasil pengolahan tahu (Gambar 4). Saili et al. (2018) melaporkan bahwa jagung kuning mengandung energi sebesar 3285,77 kkal, dengan protein kasar sebesar 9,49\%. Dedak juga mengandung serat kasar sebesar 12\% sebagai sumber serat dan pelengkap nutrisi dalam ransum Alwi (2014). Ampas tahu mengandung protein kasar sebesar 23-29\% (Mathius dan Sinurat, 2001), dan limbah sayur kol mengandung 12,64\% protein kasar sehingga memenuhi standar SNI bahan pakan dijadikan sebagai sumber protein (Superianto et al., 2018).

Bahan pakan lokal ini sangat mudah ditemui dan produksinya masih sangat melimpah. Selain itu, nutrisi yang terkandung dalam setiap bahan pakan tersebut cukup untuk memenuhi kebutuhan ternak. Masyarakat sangat antusias dalam pembuatan pakan ternak dengan bahan baku lokal dalam kegiatan ini (Gambar 5). 

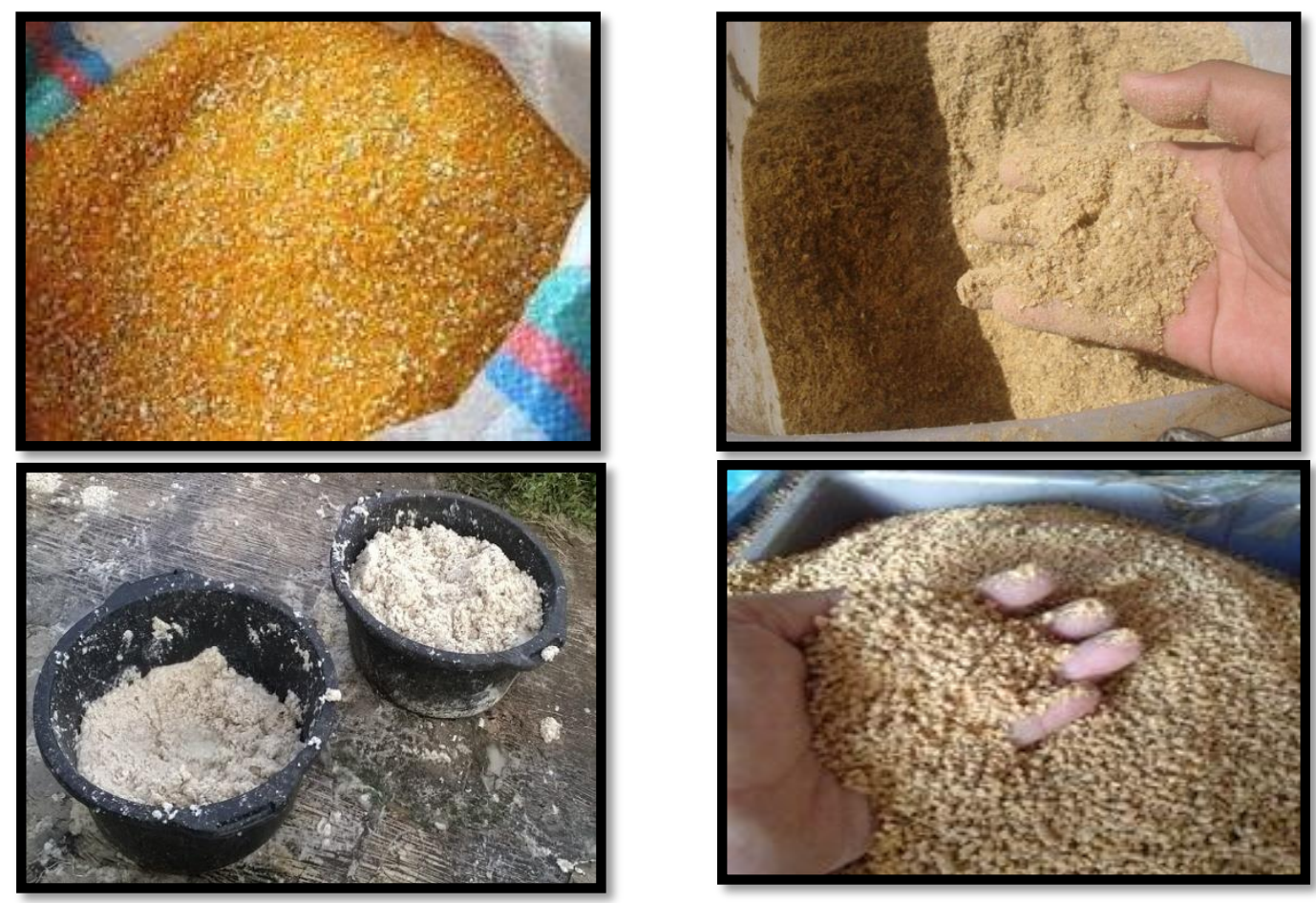

Gambar 4. Bahan Pakan Lokal Yang Tersedia Disekitar Mitra

Pembuatan pakan ternak dengan bahan baku lokal dalam kegiatan ini menggunakan teknologi sederhana yaitu fermentasi menggunakan EM4 yang bisa diperoleh mitra ditoko ternak sekitar. Teknologi fermentasi adalah teknologi pemecahan senyawa organik menjadi senyawa yang lebih sederhana dengan melibatkan mikroorganisme dalam keadaan anaerob (Pamungkas, 2011). Dalam proses ini terjadi perubahan kimia seperti perubahan struktur kimia nutrisi dari protein menjadi asam amino dan fisik yakni aroma pakan ang lebih harum dan disukai ternak, sehingga meningkatkan kecernaan pakan dan palatabilitas ternak.
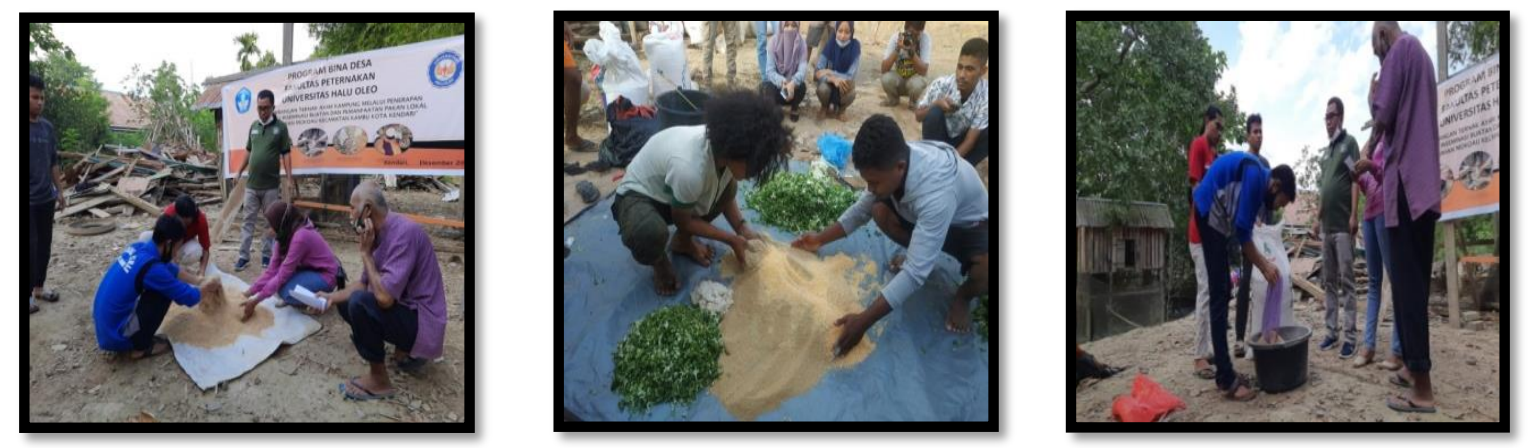

Gambar 5. Pembuatan pakan fermentasi berbasis sumber bahan pakan lokal

\section{KESIMPULAN}

Berdasarkan hasil kegian ini, dapat disimpulkan bahwa program bina desa FPT-UHO mampu meningkatkan pengetahuan dan kemampuan peternak untuk memanfaatkan teknologi IB dan teknologi pengolahan pakan berbasis bahan pakan lokal. 


\section{UCAPAN TERIMA KASIH}

Jika diperlukan ucapan terima kasih dapat diberikan kepada 1) pihak-pihak yang memberikan bantuan dana dan dukungan, 2) dukungan dari bagian dan lembaga, 3) para profesional yang memberikan kontribusi dalam penyusunan laporan.

\section{DAFTAR PUSTAKA}

Abadi M, Nafiu L O, Libriani R, Kimestri A B, dan Badaruddin R. 2020. Peningkatan Pendapatan peternak Ayam Kampung Melalui Penerapan Teknologi IB dan Mesin Tetas di Kelurahan Lalodati, Kecamatan Puuwatu Kota Kendari

Alwi W. 2014. Pengaruh Imbangan Energi - Protein Terhadap Perfoma Ayam Arab. Skripsi Peternakan. Fakultas Peternakan. Universitas Hasanudin Makasaar.

Herawati T, Anneke A, Lisa P, Dwi U dan Argi A. 2012. Peran Inseminator dalam Keberhasilan Inseminasi Buatan pada Sapi Perah. Informatika Peternakan. 21(2): 81-88.

Indarjulianto S, Irkham W, sarmin dan Claude MA. 2021. Pelatihan Penggunaan Alat Penghalus Kotoran Ternak di Kelompok Ternak Sidomaju Bantul Yogyakarta. Jurnal Pengabdian Masyarakat. 2(1): 32-37.

Mathius IW dan AP Sinurat. 2001. Pemanfaatan Bahan Pakan Konvensional untuk Ternak. Balai Penelitian Ternak Bogor. Bogor.

Pagala MA, Deki Z, Rusli B dan Hairil H. 2020. Bimbingan Teknis Pembuatan Pakan Ternak Menggnakan Bahan Baku Lokal di Sulawesi Tenggara. Jurnal Pengabdian Masyrakat Ilmu Terapan. 2(1): 65-70.

Pamungkas W. 2011. Teknologi Fermentasi Alternatif Solusi dalam Upaya Pemanfaatan Bahan Pakan Lokal. Media Akuakultur. 6(1): 43-48.

Rigianti HA. 2020. Kendala Pembelajaran Guru Sekolah Dasar di Banjarnegara. Elementary School. 7(2): 297-302.

Saili T, Fuji AA dan RAAM Sari. 2018. Aplikasi Probiotik Herbal dan Ekstrak Kerang Bakau ((Polimesoda erosa) dalam pakan Bernasis Limbah Pertanian dan Perikanan untuk Meningkatkan Produksi dan Reproduksi Ayam Buras di Sulawesi Tenggara. Laporan Akhir Penelitian. Fakultas Peternakan Universitas Halu Oleo. Kendari. (unpublish).

Superianto SAE dan Harahap AA. 2018. Nilai Nutrisi Silase Limbah Sayur Kol dengan Penambahan Dedak Padi dan Lama Fermentasi yang Berbeda. Jurnal Sains Peternakan Indonesia. 13(2): 172181. 